\title{
Salaries of HealthCare Professionals IN THE REPUBLIC OF CROATIA
}

Accepted
17. 02. 2020
Revised
14.09.2020
Published
29. 10.2020

Keywords salary, health worker, public service, health, legal norm.
ANTE KLARIĆ ${ }^{1}$, MARINA ŠVAgANOVIĆ ${ }^{2} \&$

MiRAN CVITKOVIĆ

1 Health Center Zagreb, Personnel and General Affairs, Department for Legal Personnel and General Affairs, Zagreb, Croatia.

E-mail: ante.klaric@dzz-zapad.hr

${ }^{2}$ Health Center Zagreb, Procurement Department, Zagreb, Croatia.

E-mail: marina.svaganovic@dzz-zapad.hr

${ }^{3}$ University Hospital Centre Zagreb, Zagreb, Croatia.

E-mail: mcvitkov@kbc-zagreb.hr

CORRESPONDING AUTHOR

ante.klaric@dzz-zapad.hr

Abstract Salaries of healthcare professionals in the Republic of Croatia are regulated by a series of laws and regulations. A series of regulations defining the salaries and substantive rights of healthcare professionals cannot provide a clear, uniform and complete approach to regulating the subject matter of the law. In addition to the aforementioned issues of employment status, healthcare professionals originate from a standard that is similar and common to all public servants. In doing so, the legislature does not differentiate between a healthcare professional and his profession from an activity that deals with the protection of fundamental human values: the life and health of the individual. It is these core values that should inform not only governmental regulation of salaries and wages but also all other substantive rights, as a pledge for the smooth performance of such a highly responsible service through a clear, unambiguous and norm to precise them. 
Introduction

Appropriate staffing is required to perform business in any establishment. Healthcare requires special medical knowledge and can only be performed by people who are professionally qualified and who meet applicable legal requirements. The required levels of education, apprenticeship, professional exams, professional development and other issues concerning health workers and health related matters are modulated by the relevant legal regulations (Timotić \& Anđelski, 2004: 91). Medical personnel, regardless of the extent of their scientific knowledge and achievement in technology, are always the principal agents of medicine in their domain, and where such personnel suffer from inadequacies or shortcomings of any nature, so does the overall quality of medical care (Sremac \& $\check{Z} u z a, 2002:$ 92). Human resources play a central role in the advancement of the health sector and are critical to the successful implementation of health system reform. There is ample evidence demonstrating that well-trained and qualified medical staff, when also supplied with sufficient material resources to carry out their work, and further coupled with regulated employment status, correlate with positive treatment outcomes. However, staffing potential cannot be viewed in a vacuum. The importance of medical equipment is of equal importance as both human and material resources are interconnected and extremely interdependent. As important as technological equipment is, so is the role the clinician plays in the rational application of available technology. ${ }^{1}$ The autonomy enjoyed by health professionals originates from the very nature of the health care industry and historically has been established through the right accorded to this "guild" to regulate the conduct of its members by special rules that they themselves make (Maletić, 2011: 485). The primary responsibility of the healthcare professional is to provide a health service, that is, to take all interventions and therapeutic measures on the human body, in order to prevent, identify, cure or alleviate illness, suffering, injury or mental disability.

\footnotetext{
1 Professional responsibility for the existing application of modern technology is not fully defined by legal regulations, but is in application with regard to its availability, i.e. the professional recommendation of individual companies. For the most part, these recommendations are not the result of well-planned needs for technological advancement, taking into account all relevant facts including the needs of the wider community, the morbidity of the population, or the availability of financial resources in society (Haller, 2008: 19).
} 
The term "healthcare professional" includes all-natural persons engaged in the medical profession as their permanent occupation (Urdarević, 2016: 568). According to the provisions of the Law on Health Care (Official Gazette No 100/18; 25/19), healthcare professionals are persons who have a health education and, directly in the form of a profession, provide health care to the population, with compulsory respect for the moral and ethical principles of the health profession. Healthcare professionals in the Republic of Croatia are doctors or Doctors of Medicine, Doctors of Dentistry, graduated engineers of medical biochemistry, Masters of Pharmacy, nurses, medical technicians, physiotherapists and midwives, medical biochemists, pharmaceutical technicians and other persons designated by special regulations. Eleven separate healthcare professions have been recognized under the Croatian health care system, each with its own laws, but all of which have the common goal of providing healthcare and protecting the health of everyone. through procedures and means which are, comprehensive, effective and enduring. The complexity of the jobs of these professions, as well as the need to realize these common goals, has resulted in the need for healthcare activities to be conducted and organized in a collaborative fashion (Cajnko \& Kraljić, 2018). Each profession cannot perform its work separately without regard for the work of the others. Nor can the pursuit of the goals of healthcare, that is, the provision of services and/or assistance to each individual patient, be achieved when each profession acts in isolation, and without regard to the important work carried out by the others (Klarić, 2015: 65-82). Therefore, the members of each of the above professions perform one healthcare activity and are all of public interest to the Republic of Croatia in accordance with the specific laws that regulate them. The rights and duties of healthcare professionals and other issues related to the performance of healthcare professionals who are not regulated by the Law on Health Care shall be subject to the provisions of special laws on healthcare professions.

Although this is not explicitly stipulated by law, we maintain that teachers and associates who teach at the faculties of medicine in the so-called clinical subjects in a medical facility in accordance with higher education regulations also constitute healthcare workers. They are able or obliged (due to their cumulative employment and the nature of the activity they are engaged in) to provide health services in that institution, as it would be inappropriate for a clinical teacher or associate to have no clinical experience or to provide health services in (that) medical institution (Urdarević, 2016: 568). 
The term "healthcare professional" is not limited to one category of persons that work full-time in the healthcare industry. To the contrary, the term broadly covers multilayered categories. Such activities within their profession are also performed by health associates - non-health workers who are not controlled by strict rules of education and training. Health associates - non-health workers are persons who have not completed their health education but who nevertheless work in health care industry (e.g., performing diagnostic and therapeutic procedures). This highlights the fact that they play a supporting role in the process of protecting the health of citizens (Bošković, 2002: 62).

Therefore, in the health system, apart from the previously described health activities and health workers who are authorized to perform them, there are also activities performed that are ancillary, that is, supportive activities that help facilitate and ensure the performance and implementation of health care activities. In other words, medical employees do not include all those who care for the protection of citizens' health in any way, but only those who provide this protection by direct medical means. Therefore, state institutions dealing with the organization of healthcare activities (for example, the Ministry of Health, the Croatian Institute for Health Insurance, etc.) do not belong to healthcare profession (Radišić, 2004: 31; Čizmić, Cvitković \& Klarić, 2017).

\section{The jobs of healthcare professionals and the way they are performed}

According to the provisions of the Law on Health Care, health institutions that perform health care activities in the public health service network are obliged to continuously provide health care, working in one or more shifts, standby or on-call duty, in accordance with the needs of the people. ${ }^{2}$ Maximum total duration of the beginning, ending and scheduling of working hours of both health care institutions and private health care workers in the public health service network shall be prescribed by an ordinance by the Minister (Čizmić, Cvitković \& Klarić, 2017).

\footnotetext{
${ }^{2}$ Health institutions determine by their general act the provision of health care as follows: a) in the field of emergency medicine continuously for 24 hours and on standby and on duty according to the needs of the population; b) in primary health care by organizing work in one or two shifts, shifting working hours, and being prepared and on duty according to the needs of the population; c) in the specialist-consulting field by organizing work in one or two shifts and shifting working hours to the needs of the entire populace; d) in the hospital health care industry in one or more shifts and on duty and on standby the needs of the population and certain forms of hospital treatment and the possibilities of the healthcare institution (Law on Health Care, Official Gazette No. 100/2018; 125/2019; Art. 195).
} 
According to the Rulebook, the beginning, ending and scheduling of working hours of health care institutions and private health workers in the public health service network (Official Gazette, No. 106/19) shall be regulated. The schedule of working time, and in particular the beginning and ending of working time, is determined by a general act of a health institution, taking into account the activities performed by the institution, the process of work in individual parts of it, and the season and the needs of insured persons of the Croatian Health Insurance Institute, and while at the same time respecting the principles of continuity, efficiency and availability of health care.

The schedule of working hours of 40 hours per week, or the corresponding total monthly fund of hours in healthcare institutions, must be determined to ensure that health care is available to insured persons throughout the days of the week. Notice on the start and end of working hours of individual institutions, organizational units of institutions and offices must be clearly stated on the front door of the institution, surgeries and private practice. In the event of special circumstances, disasters and epidemics requiring a different schedule of working hours of healthcare institutions or workers, the Minister responsible for health may also determine a different start and end of working hours, as well as a different re-allocation of working hours, until the special circumstances have elapsed.

According to the provisions of the Collective Agreement for the Health and Health Insurance Sector (Official Gazette, No. 29/18; 35/19; 78/19; 92/19; 56/20), fulltime employment is defined as 40 hours per week. Weekly working hours are scheduled five days a week, typically Monday through Friday. The employer is responsible for organizing work in the health and health insurance business. Additionally, the employer is obliged to organize the work in such a way that the worker performs at least the agreed full monthly fund of working hours. There are no double shift working hours in the health and medical insurance industry. In the case of re-allocation of hours and work schedules in shifts, rotations and on-call duty, the working time shall be reduced to the average full time on a monthly basis.

In jobs where it is not possible to protect the worker from harmful influences, even with the application of occupational safety measures, working time is reduced in proportion to the adverse effects produced by the working conditions on the health and capacity of workers. Examples of such jobs include open source ionizing 
radiation and the intravenous application of cytostatic, provided that they are performed two-thirds of working time. Hours worked according to the regular schedule of working hours on holidays or non-working days within the provision of the law on holidays and non-working days and Easter are recorded as regular work and counted as a regular monthly hourly rate. A worker in the health and medical insurance business in certain workplaces and jobs with special working conditions is entitled to a salary supplement. Add-ons cannot be accumulated. The basic salary will be increased for workers on the basis of a positional allowance at management positions and jobs.

The director of a healthcare institution is responsible for determining the need for on-call duty and ensuring the readiness of workers according to the criteria of providing emergency medical care, that is, the need to manage life-threatening conditions, taking into account the category of healthcare facility, the type of activities performed there, as well as the available capacities of the healthcare facility.

In accordance with the law, autonomous general acts (collective agreement, regulations, etc.) should provide maximum protection for the worker's life and health while on duty. Encompassed within this protection are working hours, rest, and of course compensation for all work (Učur, 2013).

Preparedness, intrinsically, is a separate form of work. This occurs when a worker need not be physically present in a healthcare facility but still must be available for emergency medical assistance. An emergency room physician is a typical example. Standby is the time when an employee must be prepared to respond to an employer call for work, if the need arises. During standby, the worker is not at the place where his job is performed or at any other place specified by the employer. The standby worker is obliged to respond to the call of the employer without delay and to arrive at the workplace within one hour at the latest. Standby time is 16 hours on weekdays and 24 hours on Saturdays, Sundays and public holidays. Standby compensation is paid to the employee during standby time. Standby compensation is determined in relation to the basic salary of workers and amounts to:

a) 16 hours on weekdays - three percent;

b) 24 hours on Saturdays, Sundays and holidays - five percent. 
The amount of time a standby worker is assigned to work on the job at the invitation of the employer is considered as working time and paid as overtime. For workers who have a placement allowance in the coefficient of job complexity or are entitled to this allowance based on the provisions of the Collective Bargaining Agreement, standby compensation is calculated in relation to the basic salary of the place of employment. Due to lack of staff, and sometimes due to streamlining of service, in some segments continuous health care is provided through standby. Collective agreement signatories have agreed in detail on the forms of preparedness and the method of payment. Standby time is not considered working time. A standby worker is not entitled to a minimum daily rest period after being prepared and is obliged to report to work on a regular basis, regardless of the time of day and night that he has intervened on the call. Standby fees are an integral part of pay. Standby is divided into standard standby and standby at hospital and non-on-call wards. The employer does not need to obtain the worker's consent for standby work.

The Labor Code (Official Gazette, No. 93/14; 127/17; 98/19) stipulates that working time shall not be considered as the time during which the worker is ready to respond at the invitation of the employer to perform the work, if such a need arises, whereby the worker is not at the place where his work is performed or at any other place which is determined by the half-breeder. During the standby period, the worker's obligation to perform the job depends on chance and does not have continuity, in which case the employee may, although in a limited way, manage his or her time, since he or she does not have to be present at the workplace. The employer, therefore, cannot determine the obligation of the worker's readiness by his or her decision, the rulebook or the agreement of the employer with the works council. Instead, the obligation must be contracted, either individually with the worker through a work contract or collectively with a union through a collective agreement. Otherwise, the worker has no obligation to be prepared. As a second condition for introducing the obligation of readiness for workers, the Labor Code also stipulates the necessity for establishing the amount of compensation for work on standby by means of contract. Accordingly, the employer is obliged by an appropriate act to determine the amount of compensation to which the worker is entitled due to the obligation of readiness. If we start from the fact that the time spent by the worker performing work at the invitation of the employer is considered as working time, then if the worker, for example, worked his shift according to the schedule of working hours, and then he had a standby duty after the regular working 
hours, and then during standby responded to the employer's invitation to perform work (e.g., emergency intervention) - the worker is entitled to a salary for his regular working time, remuneration at the time determined by the collective agreement or employment contract, and if, at the invitation of the employer, he performed the work, and the right to increased overtime pay (Čizmić, Cvitković \& Klarić, 2017). ${ }^{3}$

Work-by-call is considered overtime and thus paid. On a call-to-work basis, in addition to effective work, the hours required to arrive at work and return home are included in working hours that count as overtime. The Minister of Health shall determine, by special decision, the exceptional increase in the salary for the call of the explantation and transplant teams in the authorized transplant centers for the procedures of organ explantation and transplantation within the transplant program. Pay-per-call pay is an integral part of pay (Čizmić, Cvitković \& Klarić, 2017; Babić, 2012: 40-44).

Recorded work in the form of on-call and on-call work, as stated above, is considered working time and falls under the system of working time limitation, at the discretion of the employer, up to 48 hours per week. Additionally, the written consent of the worker is required. This means that on-call time cannot be considered as overtime, as is the case with on-call work. Pay based on on-call and standby work are an integral part of pay. ${ }^{4}$ If the readiness and the amount of compensation for it are not regulated by a contract of employment or a collective agreement, the worker is not obliged to be on standby at the order of the employer and should therefore not bear any consequences (Čizmić, Cvitković \& Klarić, 2017).

\section{The legal basis for determining the salaries of healthcare professionals}

The salaries of health care professionals are determined by a series of legal regulations and by-laws. Given that most healthcare professionals work in the public service system, it is important to show how the salaries of health care professionals in public services are determined while performing their work on a regular basis, overtime through on-call duty and on-call work.

\footnotetext{
${ }^{3}$ Pitanja i odgovori: Pripravnost i prava radnika iz rada, retrieved from http:/ / www.poslovni.hr/tips-and-tricks/ pitanja-i-odgovori-pripravnost-i-prava-radnika-iz-rada-245330. ${ }^{4}$ Dežurstvo, pripravnost i rad po pozivu, retrieved from http://upuz.hr/aktualnosti/dezurstvo-pripravnost-i-rad-po-pozivu.
} 
The Law on Salaries in Public Services (Official Gazette, No. 27/01; 39/09) regulates the principles for determining the salaries of civil servants and employees in public services (see also Senčur Peček, Laleta \& Kraljić, 2017). The salary of the clerk and the employee is the product of the coefficient of complexity of the job position to which the clerk and employee are assigned and the basis for calculating the salary, plus 0.5 percent for each completed year of service. The starting point for determining the basis for calculating the salary is the draft budget for the next year, the agreement on the wage policy and the average monthly paid gross salary of employees in the Republic of Croatia in the previous year, which is established by the Central Bureau of Statistics and published in the Official Gazette. Depending on their qualifications, the positions of civil servants and employees are defined as:

a) type I jobs for which the general requirement is high qualifications;

b) jobs of type II of a kind for which the general condition is higher qualifications;

c) jobs of type III for which the general requirement is medium qualifications and;

d) jobs of type IV for which the general condition is a lower degree or elementary school.

The names of individual posts and the professional conditions for the assignment to those posts are determined by a separate law and governmental legislation. For certain posts of civil servants and employees for which a special degree is not specified as a general requirement, a decree of the government shall determine the job title, the general and professional conditions for the assignment to those posts, as well as the corresponding coefficient.

The regulations governing such matters for civil servants shall apply to the determination of job titles and professional conditions for the assignment to such posts in the Croatian Pension Insurance Institute, the Croatian Employment Service and the Croatian Health Insurance Institute. The values of the coefficients of posts are determined by a legislation of the government. The proposal for a regulation shall be submitted to the following sectors:

a) the ministry of finance;

b) the ministry responsible for each public service; and 
c) the union.

The relevant ministries and the union are required to submit their opinion within 15 days. A positive opinion is considered to have been given in situations where no ministry or trade union delivers an opinion within this deadline. In order to determine the value of job coefficients, ranges of coefficients can be determined in which the values of job coefficients in certain types can range, for:
a) type I jobs from 1.05 to 3.50 ;
b) jobs II types from 0.90 to 1.20 ;
c) posts III types 0.65 to 1.10 ;
d) jobs IV types from 0.50 to 0.75 .

To determine the value of the coefficients of jobs of the Croatian Health Insurance Institute, the regulations governing these issues for civil servants shall apply.

The Law on the Salary Base in Public Services (Official Gazette, No. 39/09; 124/09) stipulates that the salary base in public services shall be determined by a collective agreement concluded between the Government of the Republic of Croatia and the public service union, unless the collective agreement has been signed by the time of its adoption of the State Budget of the Republic of Croatia for the next year. The Decree on job titles and coefficients of complexity of jobs in public services (Official Gazette, No. 25/13; 72/13; 151/13; 09/14; 40/14; 51/14; 77/14; 83/14; 87/14; $120 / 14 ; 147 / 14 ; 151 / 14 ; 11 / 15 ; 32 / 15 ; 38 / 15 ; 60 / 15 ; 83 / 15 ; 112 / 15 ; 122 / 15$; 10/17; 39/17; $40 / 17$ - correction; 74/17; 122/17; 9/18; 57/18; 59/19; 79/19; $119 / 19 ; 50 / 20)$ determined the coefficients for the positions and positions in public services, and consequently for healthcare professionals.

The Basic Collective Agreement for Civil Servants and Employees (Official Gazette, No. $128 / 18 ; 47 / 18 ; 123 / 19 ; 66 / 20)$ establishes the rights and obligations arising from the work and on the basis of the work of civil servants and employees in the public services to which the Law on Civil Service applies. 
The Collective Agreement for the Health and Health Insurance Sector (Official Gazette, No. 29/18; 35/19; 78/19; 92/19; 56/20) regulates the rights and obligations arising from the work and on the basis of the work of workers in the health and health insurance industry, for which the funds exceeding fifty percent of the costs of salaries and other material rights of workers are secured in the state budget.

A worker in the health and medical insurance business in certain workplaces and jobs with special working conditions is subject to salary review.

The basic salary will be increased for the workers on the basis of the position allowance at certain jobs which, because of the exceptional responsibility for the life and health of the people, the health workers receive special salary packages.

As is evident due to the complex web of legal norms, baselines and prescribed supplements, it is difficult to determine with any precision the salary of a healthcare professional. The consequence of all this is the sheer number of complaints, litigation filed and initiated by healthcare professionals in cases of miscalculation and payment of salaries. Considering the equations involved, in which it is necessary to calculate the specific coefficients of individual jobs with a number of parameters, special allowances and criteria for additional salary increases, it is undoubted that errors frequently occur. The most recent error in the calculation of salaries of health workers has been the failure to accurately calculate overtime benefits. Therefore, the health care workers, while working overtime, did not calculate the supplements to the correct scientific degree, but instead calculated them in the amount of salary only in regular work. Translated subject matter would mean that, for example, a doctor under the system is paid by the doctor of science only until the end of his working hours, and if he works part-time and even on the same day, then he is only a doctor without a recognized doctor of science degree. ${ }^{5}$

${ }^{5}$ https://direktno.hr/domovina/prekovremeni-rad-oko-4000-tuzbi-lijecnika-zbog-neisplacenih-sati-145121/ 
The payroll of health care providers is carried out through a single and centralized payroll calculation, Centralized Payroll (COP). COP is a business-to-business system that supports the management of expenditure related to human resources costs in the public sector. COP provides payroll and payroll for more than 2,100 public sectors.

Pursuant to the agreement on the Provision of Services of Centralized Payroll and Human Resources Management dated 25 October 2013, the Government of the Republic of Croatia entrusted the Financial Agency with the tasks of establishing and supporting an information system.

\section{$4 \quad$ Law on salaries of healthcare professionals}

The constitutional and legal basis for the redefinition of the legal status of health care workers in determining wages is formally contained in Article 2, paragraph 4 of the Constitution of the Republic of Croatia (Official Gazette, No. 85/10; consolidated text and 5/14 - Decision of the Constitutional Court of the Republic of Croatia).

The basis of these amendments is reflected in the need to implement the provision of Article 16 of the Constitution of the Republic of Croatia, which protects health as a basic social determinant with legal order and public morality.

The protection of public health as a constitutional right is explicitly stated in Articles 32, 34, 50, 59, 65, 70, and 135 of the Constitution of the Republic of Croatia. Article 59 , in particular, guarantees everyone, society and the individual the right to health care in accordance with the law.

Article 4 of the Law on Health Care (Official Gazette, No. 100/18; 125/19) defines healthcare as a set of measures, services and activities for the preservation and improvement of health, disease prevention, early detection of diseases, timely treatment, and health care and rehabilitation. Article 5 of the Law clearly and decisively stipulates that every person is entitled to health care, and that (citing paragraph 3): "No one shall endanger the health of others." In Articles 6 and 7 of the same Law, special emphasis was placed on the duty and obligation of the State, 
that is, the Republic of Croatia, to ensure the conditions necessary for the implementation of health care, and to preserve and protect public health.

For the purpose of implementation and provision of health care measures, Article 28 of the said Law defines "health care activity as an activity of special interest for the Republic of Croatia, which is performed as a public service, performed by health care professionals by implementing certain health care measures and activities in health institutions, companies, and through private practice".

Article 1 of the Law on Medical Practices (Official Gazette, No. 121/03; 117/08) defines a doctor as a "basic, independent and responsible provider of health care activity of particular interest to the Republic of Croatia and as such providing health care to every individual and to the entire population". Article 3 of the Law on Medical Practice explicitly states that "the purpose of the medical activity is to protect the health of the individual, family and the general population".

Reading the constitutional and legal provisions in question together, it is undeniable that health care and healthcare professionals, as ensurers of the lives and health of individuals, must have primary status both in society and in the workplace. In this regard, in order to protect and secure the performance of the health care activity, it is necessary that the health professionals themselves have a clearly defined material status. Accomplishing this objective in turns requires guaranteed and precise standards that clearly define the criteria for salaries and other substantive rights. It is critically important, for the welfare of the Croatian public, and to fulfill their legally protected rights, that healthcare professionals perform their work at the highest possible professional level. Ensuring that they are properly compensated through legislation that is well-structured and easy to calculate helps ensure quality performance and in turn protects the health and safety of the public.

In addition, by ensuring their substantive rights (economic and otherwise) are properly met, healthcare professionals will be provided with the necessary security to ensure that their existential material status is clear and identifiable. In this regard, adequate and timely, professional and professional provision of health care to all third parties will be ensured, and the healthcare professional will be positioned as a person protected in the performance of their activities by the system and state bodies. 
In contradistinction to healthcare professionals, first-instance officials have clearly defined parameters for determining salary and labor-legal status, as these are regulated by a legal norm in the form of a separate Law on Salaries of Judges and Judicial Officials (Official Gazette, No. 10/99; 25/00; 01/01; 30/01; 59/01; 114/01; 116/01; 64/02; 153/02; 154/02; 17/04; 08/06; 142/06; 34/07; 134/07; 146/08; $155 / 08$; 39/09; 155/09; 14/11; 154/11; 12/12; 143/12; 100/14; 147/14; 120/16; 16/19). The laws relating to judges and other judicial officials are more objective (objective criteria) and less subjective, as is the case with health professionals, and since the latter criteria have this subjective component, they are more difficult to apply in practice, which in turn leads to disputes; claims; litigation; frustration; uncertainty; anger; and in the end, unhappy and frustrated healthcare professionals. The same legal solution left the possibility of fixing special salaries and increasing salaries for judicial officials.

On the other hand, unlike judicial officials, health professionals are placed on par with other public servants in determining their salary. Various salary supplements have been established in an attempt to better balance the salaries and substantive rights of healthcare workers, in accordance with the importance of the activities they perform through the provisions of the branch Collective Agreement. However, as we have demonstrated, the existing criteria are too subjective in nature, too difficult to implement in practice, and too lacking in objective criteria. Consequently, the current legislation has resulted in an ambiguous legal order and has led to difficulties in the calculation of salaries, especially in calculating compensation in cases involving overtime work.

Therefore, a legitimate question is why it is not in the interest of the state and the system to regulate the issue of salaries and other substantive rights of healthcare professionals through specific and precise legal norms. First of all, we will highlight several fundamental reasons why such norms must be enacted. The first is that, just as is the case with judicial officials, the standards that define wages and other material rights for health professionals must be clear and precise, because the work and activities they perform is of utmost importance not only for the life and health of every individual but also for the safeguarding of fundamental values of society and state order. Furthermore, establishing clear criteria for the calculation and definition of basic salary and other material matters helps promote the dignity of members of the profession who care for the life and health of others. The third equivalent reason 
is that experience has shown that the salaries of healthcare professionals are insufficient and vaguely defined. Therefore, the existing approach, as set forth in current general regulations and legal norms is inadequate and unsatisfactory, in that they fail to guarantee certainty. They must be subject to objective criteria and standards so that salaries and other substantive rights can be clearly and easily determined, just as is true with the judiciary. Subjective criteria, i.e. vaguely defined allowances for positions and positions in the health care system, have been a failure and if this situation is left unabated will further undermine the healthcare system, to the detriment of all Croatian citizens.

The decision of the Constitutional Court U-I-4039/2009, U-I-25427/2009, U-I$195 / 2010$ is symptomatic of the fact that it takes a clearly articulated view of the need for judicial officials or judges to have a special law defining not only their salaries but also their substantive rights. The basic conclusions of the constitutional decision are that the material independence of the judges is necessary for the professional administration of justice and the preservation of public order as core values.

All elements of judges' salaries and benefits must be appropriate to the dignity of the profession and the burden of responsibility. All regulations regarding judges' remuneration and material costs require an accurate and precise legal standard.

\section{$5 \quad$ Conclusion}

Considering all of the above, the general question may be asked, are not the health professions also dignified? Is it not true that the healthcare professions have a particular burden of responsibility? Do not the health professions need a precise and determinative standard for salaries and wages in view of the fact that it is indisputable that they provide a close nexus to the protection of health and life, which are the most fundamental human values. Everything indicates that this is how it should be. The State urgently needs to fully appreciate health care and the critical role healthcare professionals play as guardians and bulwarks of the health and welfare of society and to take concrete measures to improve their material status. Material and financial security will contribute to healthcare professionals being more satisfied at their workplace, which will ultimately lead to better health care for all citizens of Croatia. This goal will only be achieved when the Croatian legislator enacts special laws on 
salaries of healthcare professionals. Those laws also must be specific and easy to apply, just as is the case with judicial officers, who similarly are an integral part of our society.

\section{References}

Babić, I. (2012) Rad u dežurstvu, rad u pripravnosti i rad po pozivu kod zdravstvenih radnika rad po pozivu kod zdravstvenih radnik, Prilog časopisu Računovodstvo, revizija i financije, (4), pp. 40-44.

Bošković, Z. (2002) Profesionalno obrazovanje zdravstvenih djelatnika, Informator, (4987-4990), pp. 62.

Cajnko, P. \& Kraljić, S. (2018) Management Coaching Model and Impact of its Activities on Employee Satisfaction. LeXonomica, 10(2), pp. 133-148.

Čizmić, J., Cvitković, M. \& Klarić, A. (2017) Zdravstveno strukovno staleško pravo, (Maribor: University of Maribor Press).

Haller, H. (2008) Medicinski pogled na liječničku odgovornost, In: Gradanskopravna odgovornost u medicini (Zagreb: HAZU), p. 19.

Klarić, A. (2015) Medicinsko pravo - osnov definiranja komorskih prava, In: Zbornik radova s međunarodnog simpozija ,Medicinsko pravo u sustavu zdravstvene djelatnosti“, (Split: Sveučilište u Splitu - Pravni fakultet), pp. 65-82.

Maletić, D. (2011) Profesionalna sloboda lekara, Pravni život, (9), p. 485.

Radišić, J. (2004) Medicinsko pravo (Beograd: Nomos).

Senčur Peček, D., Laleta, S. \& Kraljić, S. (2017) Labour law implications of outsourcing in public sector, Lex Localis - special issue, 15(3), pp. 705-723.

Sremac, Đ. \& Žuža, B. (2002) Hrvatsko ₹dravstveno qakonodavstvo 1830.-1941 (Zagreb: Školska Knjiga).

Timotić, B. \& Anđelski, H. (2004) Zdravstveno zakonodavstvo (Beograd: Elita - Medica).

Učur, Đ. M. (2013) Radno vrijeme u đežurstvu, retrieved from: https://burza.com.hr/portal/radnovrijeme-u-dezurstvu/9261 (6 October 2020).

Urdarević, B. (2016) Zdravstveni radnici kao pružaoci zdravstvenih usluga i stručna greška lekara, In: Zbornik radova „Usluge $i$ zastita korisnika“" (Kragujevac), p. 568.

\section{Legislation}

Kolektivni ugovor za zdravstvo i djelatnost zdravstvenog osiguranje (Collective Agreement for the Health and Health Insurance Sector): Official Gazette RH, No 29/18, 35/19, 78/19, 92/19, $56 / 20$.

Pravilnik o početku, završetku i rasporedu radnog vremena zdravstvenih ustanova i privatnih zdravstvenih radnika u ordinaciji u mreži javnozdravstvene službe (Rulebook on the beginning, ending and scheduling of working hours of health care institutions and private health workers in the office in the public health service network): Official Gazette RH, No 106/19.

Temeljni kolektivni ugovor za službenike i namještenike u javnim službama (Basic Collective Agreement for Civil Servants and Employees): Official Gazette RH, No 128/18, 47/18, $123 / 19,66 / 20$.

Uredba o nazivima radnih mjesta i koeficijentima složenosti poslova u javnim službama (Decree on job titles and coefficients of complexity of jobs in public services): Official Gazette RH, No 25/13, $72 / 13,151 / 13,09 / 14,40 / 14,51 / 14,77 / 14,83 / 14,87 / 14,120 / 14,147 / 14,151 / 14,11 / 15$, $32 / 15,38 / 15,60 / 15,83 / 15,112 / 15,122 / 15,10 / 17,39 / 17,40 / 17$ - Correction, 74/17, $122 / 17,9 / 18,57 / 18,59 / 19,79 / 19$ and $119 / 19$.

Ustav Republike Hrvatske (Constitution of the Republic of Croatia): Official Gazette RH, No. 85/10, consolidated text and 5/14 - Decision of the Constitutional Court of the Republic of Croatia.

Zakon o liječništvu (Law on Medical Practices): Official Gazette RH, No 121/03, 117/08.

Zakon o osnovici plaće u javnim službama (Law on the Salary Base in Public Services): Official Gazette RH, No 39/09, 124/09. 
Zakon o plaćama sudaca i pravosudnih dužnosnika (Law on Salaries of Judges and Judicial Officials): Official Gazette RH, No 10/99, 25/00, 01/01, 30/01, 59/01, 114/01, 116/01, 64/02, 153/02, $154 / 02,17 / 04,08 / 06,142 / 06,34 / 07,134 / 07,146 / 08,155 / 08,39 / 09,155 / 09,14 / 11$, $154 / 11,12 / 12,143 / 12,100 / 14,147 / 14,120 / 16,16 / 19$

Zakon o plaćama u javnim službama (Law on Salaries in Public Services): Official Gazette RH, No 27/01, 39/09.

Zakon o radu (Labor Code): Official Gazette RH, No 93/14, 127/17, 98/19.

Zakon o zdravstvenoj zaštiti (Law on Health Care): Official Gazette RH, No 100/18; 125/19. 
